\title{
PENGARUH MOTIVASI KERJA DAN KOMPENSASI TERHADAP KINERJA KARYAWAN PADA PT. BALINDO MANUNGGAL BERSAMA KOTA PALU
}

\author{
Udin Putra \\ Bakri Hasanuddin \\ Wiri Wirastuti \\ Jurusna Manajemen, Fakultas Ekonomi, Universitas Tadulako \\ Email: udinputra6@gmail.com
}

\begin{abstract}
The study aims to: (1) determine and analyze simultaneous influence of work motivation and compensation on employees' performance at PT. Balindo Manunggal Bersama of Palu City; (2) determine and analyze partial influence of work motivation on employees' performance at PT. Manunggal Bersama of Palu City; (3) determine and analyze partial influence of compensation on employees' performance at PT. Balindo Manunggal Bersama of Palu City. This research uses quantitative approach to explain the relationship between two or more variables studied with a sample of 42 employees. Data analysis technique is multiple linear regressions. The results show that (1) the sig. $F$ value of $0.002<0.05$ means that work motivation and compensation simultaneously have significant influence on employee performance; (2) the sig. $t$ value of $0.013<\alpha 0.05$ means that work motivation partially has significant influence on employee performance. (3) the sig. $t$ value of $0.821>\alpha$ 0.05 means that compensation has non-significant influence on employee performance.
\end{abstract}

Keywords: work motivation, compensation, employee performance

\begin{abstract}
ABSTRAK
Tujuan penelitian ini yaitu: (1) Untuk mengetahui dan menganalisis pengaruh motivasi kerja dan kompensasi secara serempak terhadap kinerja karyawan pada PT. Balindo Manunggal Bersama Kota Palu. (2) Untuk mengetahui dan menganalisis pengaruh motivasi kerja secara parsial terhadap kinerja karyawan pada PT. Balindo Manunggal Bersama Kota Palu. (3) Untuk mengetahui dan menganalisis pengaruh kompensasi secara parsial terhadap kinerja karyawan pada PT. Balindo Manunggal Bersama Kota Palu. Penelitian ini menggunakan penelitian kuantitatif yang merupakan penelitian yang bertujuan untuk menjelaskan hubungan antara dua variabel atau lebih dengan sampel 42 karyawan dan teknik analisis data yang digunakan adalah regresi linear berganda. Berdasarkan hasil pengujian dengan menggunakan regresi linear berganda, disimpulkan: (1) berdasarkan hasil uji regresi diperoleh sig. F sebesar 0,002 < 0,05, yang dapat diartikan bahwa variabel motivasi kerja dan kompensasi secara serempak berpengaruh signifikan terhadap variabel kinerja karyawan. (2) berdasarkan hasil uji regresi diperoleh variabel motivasi kerja memiliki tingkat signifikasi t sig. $0,013<\alpha 0,05$, yang dapat diartikan bahwa variabel motivasi kerja secara parsial berpengaruh signifikan terhadap kinerja karyawan. (3) berdasarkan hasil uji regresi diperoleh variabel kompensasi memiliki tingkat signifikasi t sig. $0,821>\alpha 0,05$, yang dapat diartikan bahwa variabel kompensasi secara parsial berpengaruh tidak signifikan terhadap kinerja karyawan.
\end{abstract}

Kata kunci: Motivasi Kerja, Kompensasi, Kinerja

\section{PENDAHULUAN}

Sumber daya manusia adalah salah satu sumber daya yang sangat penting bagi organisasi. Sumber daya manusia adalah sumber daya yang berperan aktif terhadap jalannya suatu organisasi dan proses pengambilan keputusan. Pengambilan keputusan yang terbaik yang dihasilkan oleh suatu sumber daya manusia menunjukkan kinerja seseorang dan kemampuannya untuk menganalisis suatu masalah dalam lingkup kerja dan jabatan. Sumber daya manusia merupakan satu-satunya sumber daya yang memiliki akal perasaan, keinginan, keterampilan, pengetahuan, dorongan, daya, dan karya (rasio, rasa dan karsa). Semua potensi SDM tersebut berpengaruh terhadap upaya organisasi mencapai tujuan. 
Betapapun majunya teknologi, perkembangan, informasi, tersedianya modal dan memadainya bahan, jika tanpa SDM sulit bagi organisasi itu untuk mencapai tujuan (Sutrisno, 2016:3).

Motivasi adalah suatu faktor yang mendorong seseorang untuk melakukan suatu aktivitas tertentu (Gitosudarmo dalam Sutrisno, 2016:109). Motivasi adalah pemberian daya penggerak yang menciptakan kegairahan kerja seseorang agar mau bekerja sama, bekerja efektif, dan terintegrasi dengan segala daya upayanya untuk mencapai kepuasan (Hasibuan, dalam Sutrisno, 2016:111). Menurut Mathis dan Jackson dalam Bangun (2012:312) motivasi merupakan hasrat di dalam seseorang tersebut untuk melakukan suatu tindakan dalam mencapai tujuan.

Alderfer membagi tiga kelompok kebutuhan manusia yaitu eksistensi (existence), hubungan (relatedness), dan pertumbuhan (growth). Kelompok eksistensi memperhatikan pada pemberian persyaratan keberadaan material individu, komponen ini dihubungkan dengan teori hierarki adalah kebutuhan fisiologis dan rasa aman. Kelompok hubungan yaitu hasrat yang dimiliki untuk memelihara hubungan antar individu, hasrat ini dihubungkan dengan teori hierarki adalah kebutuhan sosial dan harga diri. Sedangkan kebutuhan pertumbuhan adalah suatu hasrat intirinsik untuk perkembangan individu, komponen intrinsik dari teori hierarki kebutuhan adalah sama dengan aktualisasi diri (Bangun, 2012:321).

Menurut Handoko dalam Sutrisno, (2016:183) kompensasi adalah segala sesuatu yang diterima oleh karyawan sebagai balas jasa untuk kerja mereka. Kompensasi dapat diberikan dalam berbagai macam bentuk, seperti: dalam bentuk pemberian uang, pemberian material dan fasilitas, dan dalam bentuk bentuk pemberian kesempatan berkarier.

Menurut Hasibuan (2014:117) kompensasi merupakan pengeluaran dan biaya bagi perusahaan. Perusahaan mengharapkan agar kompensasi yang dibayarkan memperoleh imbalan prestasi kerja yang lebih besar dari karyawan. Nilai prestasi kerja karyawan harus lebih besar dari kompensasi yang dibayar perusahaan, supaya perusahaan mendapatkan laba dan kontinuitas perusahaan terjamin.

Kinerja adalah hasil pekerjaan yang dicapai seseorang berdasarkan persyaratan-persyaratan pekerjaan. Suatu pekerjaan mempunyai persyaratan tertentu untuk dapat dilakukan dalam mencapai tujuan yang disebut juga sebagai standar pekerjaan. Penilaian kinerja adalah proses yang dilakukan organisasi untuk mengevaluasi atau menilai keberhasilan karyawan dalam melaksanakan tugasnya. Penilaian dapat dilakukan dengan membandingkan hasil kerja yang dicapai karyawan dengan stadar pekerjaan. Standar pekerjaan dapat diukur melalui jumlah pekerjaan, kualitas pekerjaan, ketepatan waktu, kehadiran, dan kemampuan bekerja sama (Bangun, 2012:234).

Berdasarkan uraian yang dikemukakan, maka diduga bahwa kinerja dipengaruhi oleh motivasi dan kompensasi, sehingga untuk membuktikannya perlu dilakukan penelitian dengan tujuan:

1. Untuk mengetahui dan menganalisis apakah motivasi kerja dan kompensasi, berpengaruh secara serempak terhadap kinerja karyawan pada PT. Balindo Manunggal Bersama Kota Palu.

2. Untuk mengetahui dan menganalisis apakah motivasi kerja berpengaruh secara parsial terhadap kinerja karyawan pada PT. Balindo Manunggal Bersama Kota Palu.

3. Untuk mengetahui dan menganalisis apakah kompensasi berpengaruh secara parsial terhadap kinerja karyawan pada PT. Balindo Manunggal Bersama Kota Palu.

\section{KAJIAN LITERATUR DAN PENGEMBANGAN HIPOTESIS}

\section{Pengertian Motivasi Kerja}

Motivasi berasal dari kata motif (motive), yang berarti pendorong. Dengan demikian motivasi berarti suatu kondisi yang mendorong atau menjadi sebab seseorang melalukan suatu perbuatan/kegiatan, yang berlangsung secara sadar (Bangun, 2012:321). Mathis dan Jacson dalam Bangun (2012:312) mengatakan, motivasi merupakan hasrat di dalam seseorang menyebabkan orang tersebut melakuakan suatu tindakan. Siagian dalam Sutrisno (2016:110) mengatakan bahwa Motif adalah keadaan kejiwaan yang mendorong, mengaktifkan, atau menggerakkan dan motif itulah yang 
mengarahkan dan menyalurkan prilaku, sikap, dan tindak tanduk seseorang yang selalu dikaitkan dengan pencapaina tujuan, baik tujuan organisasi maupun juan pribadi masing-masing anggota organisasi.

Menurut Hasibuan dalam Sutrisno (2016:111) motivasi adalah pemberian daya penggerak yang menciptakan kegairahan kerja seseorang, agar mereka mau bekerja sama, bekerja efektif, dan terintegrasi dengan segala daya upayanya untuk mencapainya kepuasan. Motivasi yaitu membicarakan tentang bagaimana cara mendorong semangat kerja seseorang, agar mau bekerja dengan memberikan secara optimal kemampuan dan keahliannya guna mencapai tujuan organisasi, (Sunyoto, 2012:11). Sedangkan Irham (2014:143) juga mendefenisikan motivasi adalah aktivitas perilaku yang bekerja dalam usaha memenuhi kebutuhan-kebutuhan yang diinginkan.

Motivasi kerja merupakan proses yang menyebabkan seseorang berperilaku dengan cara tertentu dalam rangka memenuhi kebutuhan yang sangat individu untuk bertahan hidup, keamanan, kehormatan, pencapaian, kekuasaan, pertumbuhan dan rasa harga diri, (Bittel dan Newstrom, 1994:293), sedangkan menurut George dan Jones (2005:175) motivasi kerja sebagai suatu dorongan secara psikologis kepada seseorang yang menentukan arah dari perilaku (direction of behavior) seseorang dalam suatu organisasi, tingkat usaha (level of effort), dan tingkat kegigihan atau ketahanan dalam menghadapi suatu halangan atau masalah (level of persistence).

\section{Dimensi Motivasi Kerja}

Indikator penelitian pada variabel motivasi menggunakan Alderfer, dalam Bangun (2012:321) yaitu:

1. Eksistensi (existence), adalah suatu kebutuhan akan tetap bisa hidup sesuai dengan tingkat kebutuhan, tingkat rendah dari maslow yaitu meliputi kebutuhan fisiologis dan kebutuhan akan rasa aman

2. Hubungan (relatedness), adalah kebutuhan untuk berinteraksi dengan orang lain. Kebutuhan ini sesuai dengan kebutuhan afiliasi dari maslow

3. Pertumbuhan (growth), adalah kebutuhan yang mendorong seseorang untuk memiliki pengaruh yang kreatif dan produktif terhadap diri sendiri atau lingkungan. Realisasi dari kebutuhan penghargaan dan perwujudan diri dari Maslow.

\section{Pengertian Kompensasi}

Menurut Hasibuan (2014:117) kompensasi merupakan pengeluaran dan biaya bagi perusahaan. Perusahaan mengharapkan agar kompensasi yang dibayarkan memperoleh imbalan prestasi kerja yang lebih besar dari karyawan. Nilai prestasi kerja karyawan harus lebih besar dari kompensasi yang dibayar perusahaan, supaya perusahaan mendapatkan laba dan kontinuitas perusahaan terjamin.

Nawawi (2008:315) mengemukakan bahwa kompensasi adalah penghargaan atau ganjaran pada para pekerja yang telah memberikan kontribusi dalam mewujdkan tujuannya melalui kegiatan yang disebut bekerja, sedangkan menurut Singodimedjo dalam Sutrisno (2016:183) mengemukakan kompensasi dapat diberikan dalam berbagai macam bentuk, seperti dalam bentuk pemberian uang, pemberian material dan fasilitas dan dalam bentuk pemberian kesempatan berkarier.

\section{Dimensi Kompensasi}

Indikator penelitian pada variabel kompensasi menggunakan dimensi dari Hasibuan (2014:118), dimana kompensasi ini terdapat kompensasi langsung dan kompensasi tidak langsung yaitu:

1. Kompensasi Langsung

a. Gaji adalah balas jasa yang dibayar secara periodik kepada karyawan tetap serta mempunyai jaminan yang pasti.

b. Insentif/bonus adalah tambahan balas jasa yang diberikan kepada karyawan tertentu yang prestasinya di atas standar.

2. Kompensasi Tidak Langsung

a. Tunjangan adalah kompensasi tambahan yang diberikan berdasarkan kebijakan perusahaan terhadap semua karyawan dalam usaha untuk meningkatkan kesejahteraan karyawan.

b. Fasilitas adalah kompensasi yang diberikan kepada karyawan sebagai penunjang kelancaran untuk bekerja dan memotivasi karyawan agar semangat bekerja. 


\section{Pengertian Kinerja}

Tujuan utama manajemen sumber daya manusia adalah untuk meningkatkan kontribusi karyawan terhadap perusahaan dalam rangka mencapai produktivitas perusahaan yang bersangkutan. Dalam hai ini, keberhasilan berbagai aktivitas perusahaan sangat ditentukan oleh kinerja karyawan yang dimilikinya. Semakin baik tingkat kinerja karyawan yang dimiliki oleh perusahaan, semakin baik pula kinerja perusahaan tersebut. Menurut Bangun (2012:231) Kinerja (performace) adalah hasil pekerjaan yang dicapai seseorang berdasarkan persyaratan-persyaratan pekerjaan (job requirement). Suatu pekerjaan mempunyai persyaratan tertentu untuk dapat dilakukan dalam mencapai tujuan yang disebut juga sebagai standar pekerjaan (job standar).

\section{Dimensi Kinerja}

Menurut Bangun (2012:234) penilaian kinerja karyawan, standar pekerjaan harus dapat diukur dan dipahami secara jelas melalui:

1. Jumlah pekerjaan

Jumlah pekerjaan yang dihasilkan individu atau kelompok sebagai persyaratan yang menjadi standar pekerjaan. Setiap pekerjaan memiliki persyaratan yang berbeda sehingga menuntut karyawan harus memenuhi persyaratan tersebut baik pengetahuan, keterampilan, maupun kemampuan yang sesuai.

2. Kualitas pekerjaan

Setiap karyawan dalam perusahaan harus memenuhi persyaratan tertentu untuk dapat menghasilkan pekerjaan sesuai kualitas yang dituntut suatu pekerjaan tertentu. Setiap pekerjaan memiliki standar kualitas tertentu yang harus disesuaikan oleh karyawan untuk dapat mengerjakannya sesuai ketentuan. Karyawan memiliki kinerja baik bila dapat menghasilkan pekerjaan sesuai persyaratan kualitas yang dituntut pekerjaan tersebut.

3. Ketepatan waktu

Jenis pekerjaan tertentu harus diselesaikan tepat waktu, karena memiliki ketergantungan atas pekerjaan lainnya. Jadi, apabila pekerjaan pada suatu bagian tertentu tidak selesai tepat waktu akan menghambat pekerjaan pada bagian lain, sehingga mempengaruhi jumlah dan kualitas hasil pekerjaan.

4. Kehadiran

Ada tipe pekerjaan yang menuntut kehadiran karyawan selama delapan jam sehari untuk lima hari kerja seminggu. Kinerja karyawan ditentukan oleh tingkat ke hadiran karyawan dalam mengerjakannya.

5. Kemampuan kerja sama

Untuk jenis pekerjaan tertentu mungkin harus diselesaikan oleh dua orang karyawan atau lebih, sehingga membutuhkan kerja sama antar karyawan sangat dibutuhkan. Kinerja karyawan dapat dinilai dari kemampuannya bekerja sama dengan rekan sekerja lainnya. 


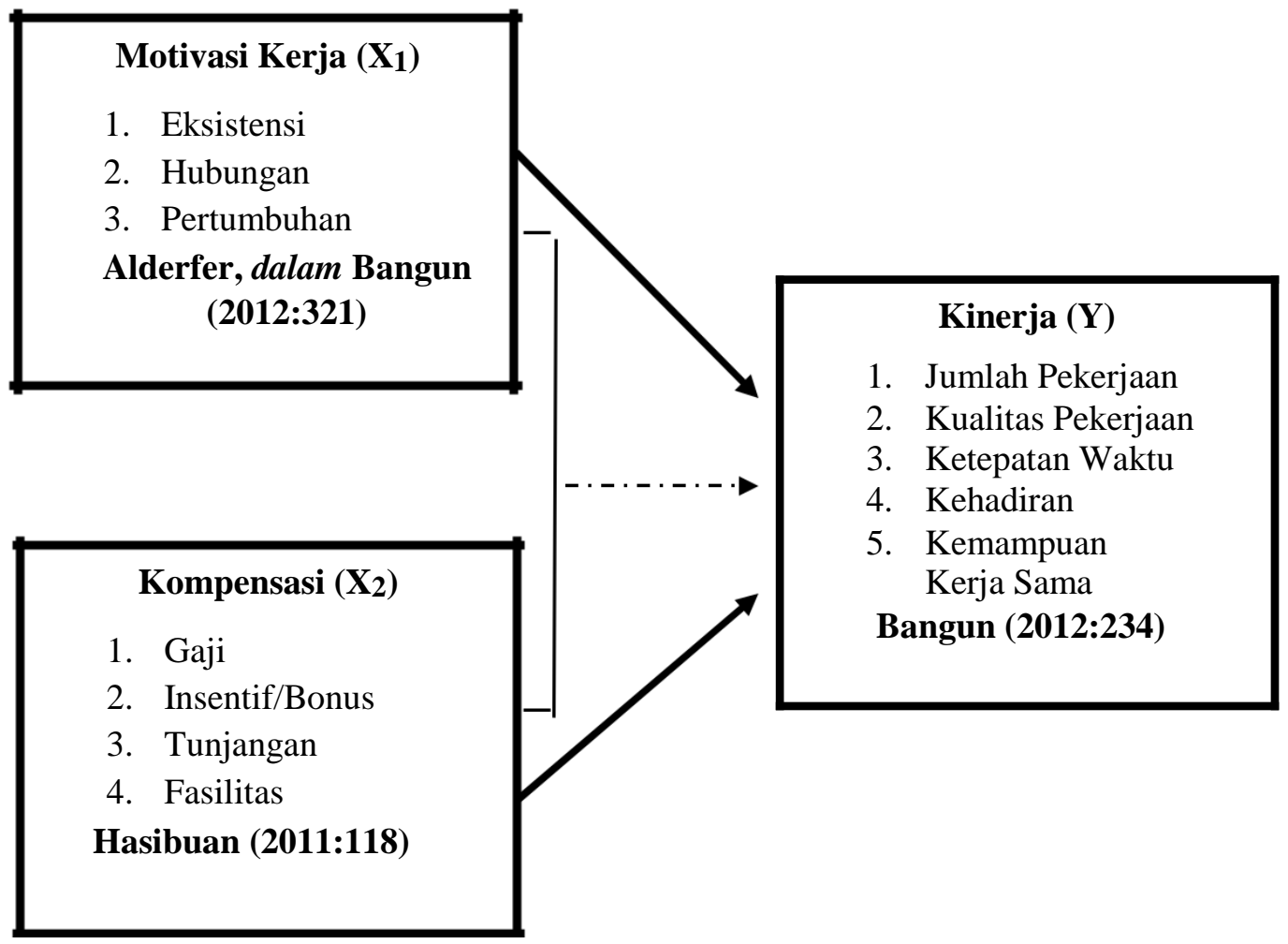

\section{Gambar 1. Kerangka Pemikiran}

Keterangan:

Pengaruh secara serempak

Pengaruh secara parsial

\section{Hipotesis}

Hipotesis merupakan jawaban sementara terhadap rumusan masalah peneliti. Dalam hipotesis terdapat istilah signifikan yang berarti hipotesis penelitian yang telah terbukti pada sampel itu (baik deskriptif, komparatif, maupun asosiatif). Adapun hipotesis yang diajukan dalam penelitian ini adalah:

1. Motivasi kerja dan kompensasi berpengaruh secara serempak terhadap kinerja karyawan pada PT.

Balindo Manunggal Bersama Kota Palu.

2. Motivasi kerja berpengaruh secara parsial terhadap kinerja karyawan pada PT. Balindo Manunggal Bersama Kota Palu.

3. Kompensasi berpengaruh secara parsial terhadap kinerja karyawan pada PT. Balindo Manunggal

Bersama Kota Palu.

\section{METODE PENELITIAN}

Penelitian ini didesain menggunakan pendekatak kuantitatif dengan mengambil sampel dari populasi penelitian. Menurut Sunusi (2014:101) sampel adalah bagian dari populasi yang dijadikan sebagai objek penelitian. Jumlah populasi penelitian ini adalah 42 karyawan dan untuk menentukan besarnya keseluruhan sampel digunakan rumus Slovin dengan rumus sebagai berikut:

Atas dasar rumus di atas, maka dapat dihitung jumlah sampel penelitian sebagai berikut: 
Tabel dibawah ini menunjukkan jumlah responden pada tiap-tiap devisi PT. Balindo Manunggal Bersama Kota Palu.

Tabel 1

Karakteristik Responden PT. Balindo Manunggal Bersama Kota Palu

\begin{tabular}{|c|c|l|}
\hline No & Bagian dalam Perusahaan & Jumlah Karyawan \\
\hline 1 & General Manager & - \\
\hline 2 & Sales Devision & - \\
\hline 3 & Service Devision & - \\
\hline 4 & Spare parts & - \\
\hline 5 & Bagian Umum & - \\
\hline \multicolumn{2}{|c|}{} \\
\hline
\end{tabular}

\section{HASIL DAN PEMBAHASAN}

\section{HASIL PENELITIAN}

Tabel 2

Hasil Perhitungan Regresi Linear Berganda

\begin{tabular}{|c|c|c|c|c|c|c|}
\hline \multirow{2}{*}{\multicolumn{2}{|c|}{ Model }} & \multicolumn{2}{|c|}{$\begin{array}{c}\text { Unstandardized } \\
\text { Coefficients }\end{array}$} & \multirow{2}{*}{$\begin{array}{c}\begin{array}{c}\text { Standardized } \\
\text { Coefficients }\end{array} \\
\text { Beta }\end{array}$} & \multirow[b]{2}{*}{$\mathrm{T}$} & \multirow[b]{2}{*}{ Sig. } \\
\hline & & $\mathrm{B}$ & Std. Error & & & \\
\hline \multirow[t]{3}{*}{1} & (Constant) & 2,135 & ,497 & & 4,292 &, 000 \\
\hline & Motivasi Kerja & ,428 & , 164 & ,494 & 2,614 &, 013 \\
\hline & Kompensasi & ,033 &, 145 & ,043 & ,228 & 821 \\
\hline \multicolumn{2}{|c|}{$\begin{array}{l}\text { Multiple R } \\
\text { R Square = } \\
\text { Adjusted R-Square = }\end{array}$} & & $\begin{array}{l}\text { F- hit } \\
\text { Sig } \\
\alpha\end{array}$ & $\begin{array}{l}=7,417 \\
=.002 \\
=0.05\end{array}$ & & \\
\hline
\end{tabular}

Berdasarkan nilai dari tabel 2 di atas, maka persamaan regresi linear berganda dapat dirumuskan sebagai berikut:

$$
\mathbf{Y}=\mathbf{2 , 1 3 5}+\mathbf{0 , 4 2 8 X 1}+\mathbf{0 , 0 3 3 X 2}+\mathrm{e}
$$

Persamaan regresi dalam penelitian ini menggunakan nilai unstandardized coefisien beta, karena ukuran variabel independen menggunakan ukuran variabel yang sama. Hal ini sesuai pendapat yang dikemukankan oleh Ghozali (2006:88), yang menyatakan jika ukuran variabel independen tidak sama (ada $\mathrm{kg}, \mathrm{Rp}$, liter dll), maka sebaiknya interpretasi persamaan regresi menggunakan standartdized beta, jika sebaliknya ukuran variabel independen sama maka menggunakan interpretasi persamaan regresi unstandardized coefisien beta. 
Persamaan di atas menunjukkan bahwa variabel independen $\left(\mathrm{X}_{1}\right.$ dan $\left.\mathrm{X}_{2}\right)$ memberi pengaruh positif terhadap variabel dependen $(\mathrm{Y})$. Berdasarkan hasil rekapitulasi analisis regresi linear berganda dapat dilihat pengaruh hasil uji determinan $\mathrm{R}$ Square sebesar 0,276 atau 27,6\%, jadi variabel $\left(\mathrm{X}_{1}\right.$ dan $\left.\mathrm{X}_{2}\right)$ memiliki pengaruh terhadap kinerja karyawan sebesar $27,6 \%$, sedangkan sisanya dipengaruhi variabel lain yang tidak diteliti. Adapun tingkat keeratan hubungan antara variabel indevenden terhadap variabel dependen yaitu kinerja karyawan pada PT. Balindo Manunggal Bersama Kota Palu dengan nilai Multiple $\mathrm{R}$ sebesar 0,525 atau 52,5\%, melalui hasil Multiple $\mathrm{R}$ menunjukkan bahwa tingkat keeratan variabel sebesar $52,5 \%$. Sedangkan Ajusted $R$ Square memiliki nilai sebesar 0,238 atau $23,8 \%$, yang menunjukkan bahwa pengaruh variabel indevenden secara keseluruhan sebesar 23,8\%.

1. Untuk nilai konstanta sebesar 2,135 berarti kinerja karyawan pada PT. Balindo Manunggal

Bersama Kota Palu sebelum adanya variabel independen adalah sebesar 2,135.

2. Nilai koefisien regresi variabel motivasi kerja $\left(X_{1}\right)$ sebesar 0,428 , artinya jika motivasi kerja mengalami kenaikan satu satuan, maka kinerja karyawan pada PT. Balindo Manunggal Bersama Kota Palu akan mengalami peningkatan sebesar 0,428 atau sebesar $42,8 \%$, satuan dengan asumsi variabel indevenden lainnya bernilai tetap.

3. Nilai koefisien regresi variabel kompensasi $\left(\mathrm{X}_{2}\right)$ sebesar 0,033 , artinya jika kompensasi mengalami kenaikan satu satuan, maka kinerja karyawan pada PT. Balindo Manunggal Bersama Kota Palu akan mengalami peningkatan sebesar 0,033 atau sebesar 3,3\%, satuan dengan asumsi variabel indevenden lainnya bernilai tetap.

\section{Uji F}

Berdasarkan hasil uji regresi pada tabel 3 diperoleh $\mathrm{F}$ hitung sebesar 7,417 dengan tingkat signifikansi $0,002<0,05$, yang dapat diartikan bahwa variabel motivasi kerja $\left(\mathrm{X}_{1}\right)$ dan kompensasi $\left(\mathrm{X}_{2}\right)$ secara serempak berpengaruh signifikan terhadap variabel kinerja $(\mathrm{Y})$. Kemudian hasil uji determinasi (kehandalan model) memperlihatkan nilai adjust $R$-Square $=0,238$ atau 23,8\%, variabel tidak bebas dipengaruhi oleh kedua variabel bebas, sebaliknya variabel tidak bebas dipengaruhi oleh variabel lain yang tidak diteliti.

Berdasarkan hasil tersebut, maka dengan demikian hipotesis pertama bahwa "motivasi kerja dan kompensasi secara serempak berpengaruh signifikan terhadap kinerja karyawan pada PT. Balindo Manunggal Bersama Kota Palu” berdasarkan uji F ternyata terbukti. Berdasarkan berdasarkan hasil tersebut dapat disimpulkan bahwa $\mathrm{H}_{\mathrm{o}}$ ditolak dan $\mathrm{H}_{\mathrm{a}}$ diterima.

Tabel 3 ANOVA ${ }^{\text {a }}$

\begin{tabular}{|ll|r|r|r|r|c|}
\hline \multicolumn{2}{|l|}{ Model } & $\begin{array}{c}\text { Sum of } \\
\text { Squares }\end{array}$ & Df & Mean Square & F & Sig. \\
\hline 1 & Regression & 2,417 & 2 & 1,209 & 7,417 &, $002^{\mathrm{b}}$ \\
\cline { 2 - 7 } & Residual & 6,355 & 39 &, 163 & & \\
\cline { 2 - 7 } & Total & 8,773 & 41 & & & \\
\hline
\end{tabular}

\section{Uji t}

Tabel 4 Coefficients ${ }^{a}$

\begin{tabular}{|c|c|c|c|c|c|}
\hline \multirow[b]{2}{*}{ Model } & \multicolumn{2}{|c|}{$\begin{array}{c}\text { Unstandardized } \\
\text { Coefficients }\end{array}$} & \multirow{2}{*}{$\begin{array}{c}\begin{array}{c}\text { Standardized } \\
\text { Coefficients }\end{array} \\
\text { Beta } \\
\end{array}$} & \multirow[b]{2}{*}{$\mathrm{t}$} & \multirow[b]{2}{*}{ Sig. } \\
\hline & $\mathrm{B}$ & Std. Error & & & \\
\hline 1 (Constant) & 2,135 & ,497| & & 4,292 &, 000 \\
\hline Motivasi Kerja & ,428 &, 164 & ,494 & 2,614 & ,013 \\
\hline Kompensasi & ,033 & , 145 & ,043 & ,821 & ,821 \\
\hline
\end{tabular}




\section{Motivasi Kerja $\left(\mathrm{X}_{1}\right)$}

Variabel motivasi kerja memiliki tingkat signifikansi t sig. $(0,013)<\alpha(0,05)$. Hal ini bermakna secara parsial variabel motivasi kerja di tempat kerja berpengaruh signifikan terhadap kinerja karyawan pada PT. Balindo Manunggal Bersama Kota Palu. Berdasarkan hasil di atas, maka hipotesis kedua untuk variabel motivasi kerja di tempat kerja dalam penelitian yang telah dilakukan dalam hal ini terbukti ( $\mathrm{H}_{\mathrm{o}}$ ditolak dan $\mathrm{H}_{\mathrm{a}}$ diterima). Artinya variabel motivasi kerja di tempat kerja berpengaruh signifikan terhadap kinerja karyawan pada PT. Balindo Manunggal Bersama Kota Palu.

2. Kompensasi $\left(\mathrm{X}_{2}\right)$

Variabel kompensasi memiliki tingkat signifikansi t sig. $(0,821)>\alpha(0,05)$. Hal ini bermakna secara parsial variabel kompensasi di tempat kerja berpengaruh tidak signifikan terhadap kinerja karyawan pada PT. Balindo Manunggal Bersama Kota Palu. Berdasarkan hasil di atas, maka hipotesis ketiga untuk variabel kompensasi di tempat kerja dalam penelitian yang telah dilakukan dalam hal ini tidak terbukti ( $\mathrm{H}_{\mathrm{o}}$ diterima dan $\mathrm{H}_{\mathrm{a}}$ ditolak). Artinya variabel kompensasi di tempat kerja berpengaruh tidak signifikan terhadap kinerja karyawan pada PT. Balindo Manunggal Bersama Kota Palu.

\section{PEMBAHASAN}

Motivasi Kerja dan Kompensasi Berpengaruh Secara Serempak Terhadap Kinerja Karyawan

Hasil penelitian regresi menunjukan adanya pengaruh positif dan signifikan dari variabel motivasi kerja dan kompensasi terhadap kinerja karyawan pada PT Balindo Manuggal Bersama Kota Palu. Hal ini membuktikan bahwa kinerja karyawan pada PT. Balindo Manunggal Bersama Kota Palu dapat ditingkatkan bila ada pengaruh dari kedua variabel tersebut.

Variabel motivasi kerja dan kompensasi merupakan faktor yang mempengaruhi kinerja karyawan di PT. Balindo Manunggal Bersama Kota Palu. Dalam hal ini motivasi kerja mempengaruhi sikap karyawan untuk saling berinteraksi dengan karyawan lain dan selalu bertanggung jawab dengan tugas yang diberikan. Sedangkan kompensasi mempengaruhi semangat kerja yang dimiliki karyawan dan selalu bertanggung jawan atas tugas-tugas yang diberikan.

Tujuan utama setiap organisasi merancang sistem kompensasi untuk memotivasi karyawan dalam meningkatkan kinerjanya serta mempertahankan karyawan yang berkompoten, untuk mendorong kinerja para karyawan secara terus-menerus dan berkesinambungan, maka hal itu harus dilakukan secara sistematis, karena kompensasi merupakan titik sentral dalam hubungan kerja, (Schuler dan Jackson dalam Sutrisno, 2016:195).

Berdasarkan hasil penelitian yang dilakukan menunjukkan bahwa PT. Balindo Manunggal Bersama Kota Palu harus bisa mempertahankan karena kedua variabel ini sudah berada pada interpretasi yang baik/tinggi. Penelitian ini sejalan dengan penelitian yang dilakukan oleh Yuli Suwati (2013:50) dengan judul "Pengaruh Kompensasi dan Motivasi Kerja Terhadap Kinerja Karyawan Pada PT. Tunas Hijau Samarinda" yang menyatakan bahwa semakin tinggi nilai variabel bebas yaitu motivasi kerja dan kompensasi maka semakin tinggi pula kinerja karyawan. Penelitian ini juga menunjukkan bahwa motivasi kerja dan kompensasi berpengeruh secara serempak terhadap kinerja karyawan pada

\section{Motivasi Kerja Berpengaruh Signifikan Terhadap Kinerja Karyawan}

Berdasarkan hasil penelitian uji regresi diketahui bahwa motivasi berpengaruh signifikan terhadap kinerja karyawan pada PT. Balindo Manunggal Bersama Kota Palu. Ini artinya bahwa semakin baik motivasi, maka semakin baik pula kinerja karyawan. Hasil ini sekaligus mengindikasikan bahwa motivasi yang terdiri dari eksistensi, hubungan dan pertumbuhan. Tepat untuk diterapkan pada karyawan pada PT. Balindo Manunggal Bersama Kota Palu.

Hasil penelitian ini memberikan makna bahwa selama ini karyawan cenderung memperhatikan sikap respon yang positif terhadap kebijakan pimpinan dengan berusaha menyelesaikan tugas-tugas yang diberikan walaupun ada beberapa karyawan yang masih melanggar aturan perusahaan. Selain itu, 
karyawan pada PT. Balindo Manunggal Bersama Kota Palu melaksanakan semua tugas dan fungsi dengan penuh rasa tanggung jawab, selama kondisi hubungan antara karyawan berlangsung secara harmonis yang dapat mendukung terbentuknya motivasi. Pada dasarnya semua konsep motivasi menganjurkan agar seseorang dapat bekerja dengan baik sesuai dengan apa yang disetujui oleh perusahaan atau dengan kata lain memberikan dorongan atau rangsangan pada setiap karyawan terhadap semua aturan yang berlaku didalam perusahaan yang harus terwujud melalui eksistensi, hubungan dan pertumbuhan sehingga tercipta pekerjaan yang memuaskan. Penelitian ini sejalan dengan penelitian yang dilakukan oleh A. Khairul Hakim (2011) dengan judul "Pengaruh Kompensasi dan Motivasi Terhadap Produktivitas Kerja Pegawai" yang menjelaskan bahwa semakin tinggi pemberian motivasi kerja maka kinerja karyawan akan semakin meningkat.

\section{Kompensasi Berpengaruh Tidak Signifikan Terhadap Kinerja Karyawan}

Berdasarkan hasil penelitian uji regresi diperoleh bahwa kompensasi berpengaruh tidak signifikan terhadap kinerja karyawan pada PT. Balindo Manunggal Bersama Kota Palu. Dapat diartikan bahwa meskipun pemberian kompensasi meningkat tidak terjadi pengaruh yang signifikan terhadap kinerja karyawan pada PT. Balindo Manunggal Bersama Kota Palu. Hal ini dikarenakan bahwa karyawan yang ada pada PT. Balindo Manunggal Bersama Kota Palu merasa bahwa kompensasi yang diberikan sudah sesuai dengan pekerjaan. Meskipun kompensasi tidak memiliki pengaruh yang signifikan bukan berarti kompensasi tidak perlu, tetapi kompensasi perlu diperhatikan untuk menghindari keluhankeluhan karyawan.

Kompensasi adalah seluruh imbalan yang diterima karyawan atas hasil kerja karyawan tersebut baik secara langsung maupun tidak langsung pada PT. Balindo Manunggal Bersama Kota Palu. Tujuan perusahaan memberikan kompensasi adalah untuk menciptakan kesadaran diantara karyawan agar dapat bekerja sama dengan perusahaan. Perusahaan juga berharap dengan adanya pemberian kompensasi, karyawan melakukan pekerjaan dengan baik sehingga dapat menciptakan kinerja yang baik juga.

Penelitian ini sejalan dengan penelitian yang dilakukan oleh Gainer Frisky Lokay (2013:779) dengan judul "motivasi kerja, kompensasi, pengembangan karir terhadap kinerja pegawai pada badan penanggulangan bencana daerah provinsi sulawesi utara" yang menyatakan bahwa kompensasi berpengaruh tidak signifikan terhadap kinerja pegawai.

\section{KESIMPULAN DAN SARAN}

\section{Kesimpulan}

Berdasarkan hasil pembahasan penelitian yang telah dikemukakan diatas, maka penulis mengambil beberapa kesimpulan dari hasil penelitian ini sebagai berikut:

1. Motivasi kerja dan kompensasi berpengaruh secara serempak terhadap kinerja karyawan pada PT. Balindo Manunggal Bersama Kota Palu.

2. Motivasi kerja berpengaruh signifikan terhadap kinerja karyawan pada PT. Balindo Manunggal Bersama Kota Palu.

3. Kompensasi berpengaruh tidak signifikan terhadap kinerja karyawan pada PT. Balindo Manunggal Bersama Kota Palu.

\section{Saran}

Berdasarkan hasil penelitian serta hal-hal yang terkait dengan keterbatasan penelitian. maka peneliti memberikan saran sebagai berikut:

1. Diharapkan PT. Balindo Manunggal Bersama Kota Palu untuk memperhatikan hubungan karyawan terutama pada bersosialisasi sesama rekan kerja agar diperoleh kinerja yang lebih baik. Apabila kita saling bersosialisasi sesama rekan kerja maka akan hubungan sesama rekan kerja akan lebih baik. 
2. Diharapkan pada PT. Balindo Manunggal Bersama Kota Palu untuk dapat memperhatikan fasilitasfasilitas agar diperoleh kinerja yang lebih baik, terutama pada fasilitas memuaskan. Apabila fasilitas karyawan terpenuhi dengan baik maka akan meningkatkan semangat kerja karyawan.

3. Pada peneliti-peneliti berikutnya yang memiliki keterkaitan untuk mengadakan riset serupa, diharapkan dapat mengembangkan hasil penelitian ini dengan memasukkan variabel-variabel lain diluar variabel penelitian ini, dan bagi pembaca semoga dapat menjadi panduan, ilmu serta bermanfaat bagi penyusunan skripsi berikutnya.

\section{REFERENSI}

Bangun, Wilson. (2012). Manajemen Sumber Daya Manusia. Jakarta: Erlangga.

Fahmi, irham. (2014). Manajemen Teori Kasus dan Solusi. Cetakan ke tiga. Bandung: Alfabeta.

George, J. M., and G. R. Jones, (2005). Essentials of Managing Organizational Behavior. 4th ed. New Jersey: Upper Saddle River

Ghozali, Imam, (2006). Aplikasi Analisis Multivariate Program SPSS. Semarang: BP Universitas Diponegoro, Semarang.

Handoko, Hani. (2012). Manajemen Personalia dan Sumber Daya Manusia. Yogyakarta: BPFE.

Hakim, A. Khairul. (2011). Pengaruh Kompensasi dan Motivasi Terhadap Produktivitas Kerja Pegawai. Jurnal Manajemen dan Bisnis, Vol 11, No 2, Hal 170-184.

Hapsa. (2011). Pengaruh Lingkungan Dan Motivasi Terhadap Kinerja Pegawai Pada Kantor Kecamatan Palsa Kabupaten Parigi Mouton. Skripsi. Fakultas Ekonomi Universitas Tadulako

Hasibuan, H. Melayu S.P, (2014). Manajemen Sumber Daya Manusia, Edisi Revisi, Bumi Aksara Jakarta.

Lokay, Gainer Frisky. (2013). Motivasi Kerja, Kompensasi, Pengembangan Karir Terhadap Kinerja Pegawai Pada Badan Penanggulangan Bencana Daerah Provinsi Sulawesi Utara. Jurnal Emba, Vol. 1, No. 4, Hal. 771-781.

Nawawi, Hadari. (2008). Manajemen Sumber Daya Manusia. Yogyakarta: Gajah Mada University Press.

Sunusi, Anwar. (2014). Metodologi Penelitian Bisnis. Cetakan Kelima. Jakarta: Salemba Empat.

Sunyoto, Danang. (2012). Manajemen Sumber Daya Manusia. Cetakan Pertama. Yogyakarta: CAPS.

Sutrisno, H. Edy. (2016). Manajemen Sumber Daya Manusia.Edisi Pertama. Jakarta: Cetakan Fajar Interpratama Mandiri, Penerbit Kencana.

Suwati, Yuli. (2013). Pengaruh Kompensasi dan Motivasi Kerja Terhadap Kinerja Karyawan pada PT. Tunas Hijau Samarinda. eJournal Ilmu Administrasi Bisnis, Vol 1, No.1, Hal 41-55. 